\title{
HEALTH ISSUES AS SECURITY ISSUES
}

\author{
Vanja Rokvić and Zoran Jeftić \\ University of Belgrade, Faculty of Security Studies
}

\begin{abstract}
$\mathrm{n}$ recent years, the concept of health security has acquired an international dimension. Global health issues incurred as a result of modern conflict, globalization, increased mobility of people, climate change, bioterrorism and emerging infectious diseases pose threats not only to national, but to global security, as well. The potential dangers of epidemics, particularly pandemics, are considered to be threats to national security and as such they have found their place in the national documents and strategies of national security. After the UN Security Council passed the first ever resolution on a health issue in 2000 Resolution 1308, which recognized the potential of an epidemic to pose a risk to stability and security and declared "peaceful war against AIDS" - as well as after a SARS outbreak in 2003, a H1N1 pandemic in 2009 and an Ebola outbreak in 2014, which the UN Security Council Resolution 2177 marked as a "threat to international peace and security", more attention has been given to the concept of global health security. In this paper, we will discuss why health issues are considered to be security issues, and present how health security has been treated in the national security strategies of individual countries, but also in global health security initiatives.
\end{abstract}

Key words: health security, global health security, global health diplomacy, emerging infectious diseases, WHO

\section{Introduction}

Gobalization and the altered security context toward the end of the Cold War brought about changes in the nature of conflicts which nowadays tend to be of the intrastate rather than the interstate kind, with many civilian casualties, refugees and displaced persons (Newman, 2004:175). They also brought about new, non-traditional security threats, that is, non-military threats such as "environmental scarcity and degradation, the spread of disease, overpopulation, mass refugee movements, nationalism, terrorism, and nuclear catastrophe" (Paris, 2001:97) as well as changes in the perception of the very concept of security. The 1994 UNDP Human Development Report underscored that the concept of security had been long interpreted in too narrow terms as security of a territory from external aggression or as protection of national interests in foreign policy and it introduced the notion of human security focused on 
people (UNDP, 1994: 22). Human security consists of seven dimensions ${ }^{1}$ whose common goal is "to safeguard the vital core of all human lives from critical pervasive threats, in a way that is consistent with long-term human fulfilment" (Alkire, 2003: 2). One of the dimensions of human security particularly relevant to this paper is health security.

The concept of health security has become topical in recent years in both academic and political discourse. Although there is no universally accepted definition of health security, analysis of literature and various reports shows that this concept is linked to the mass spread of infectious diseases threatening not only individuals but society as a whole, and to the fact that pathogen microorganisms can be used as biological weapons and the fact that certain diseases, particularly HIVIAIDS, can have social, political, economic and military implications thereby jeopardizing the stability and security of a country and region (Rushton, 2011:782; Fidler, 2003: 791-2 ). Even though, according to Ejdus, most people in developed countries believe that terrorism today is the biggest threat to security, the fact remains that disease is the cause of death in $91 \%$ of deaths worldwide (Ejdus, 2012: 106). In 2002 alone, more than 11 million people died of infectious diseases and, according to the World Health Organization (WHO), one of the biggest threats to global health is HIVIAIDS, which claimed 1.5 million lives in 2013 alone. According to World Bank data, since 1981, when AIDS was first registered, over 65 million people have become infected (World Bank, 2013), while there are currently 35 million people infected with this virus. AIDS is not only the leading cause of death in Africa today, it also has a fatality rate 10 times higher than armed conflicts.

In addition to its high mortality rate, HIVIAIDS, along with other infectious diseases, has profound consequences for health care, family, education, social cohesion, but also the security system. Elbe cites AIDS as the cause of death in $75 \%$ of fatalities among Kenya's police forces in the period between 1999 and 2000 (Elbe, 2005: 8). The armed forces are at a particularly high risk of contracting certain diseases, which affects military operational capabilities, while the risk of contracting HIVIAIDS can bear on the decision to deploy troops to a certain territory for peacekeeping operations, but also on the unwillingness of a country to host troops if there is a risk that soldiers might spread the disease.

Health issues have incalculable consequences for world economy as well. Because of its high mortality and morbidity rates, the HIVIAIDS pandemic affects workforce and causes capacity losses in key sectors of the labour market. Research shows that the pandemic throughout Africa has reduced the average social growth by 2-4\% (Dixon et al. 2002), while the 2003 SARS pandemic is estimated to have cost the world economy over 50 billion dollars (MARSH, 2008).

Poverty and poor health conditions can lead to migrations, which increases the risk of existing diseases spreading and new infectious diseases emerging. The outbreaks of SARS in 2003, H5N1 (avian flu) in 2004, H1N1 (swine flu) in 2009 and Ebola in 2014 have shown that infectious diseases can spread rapidly, jeopardizing not only human lives, but also world economy, stability and security.

As a result of all this, health issues have started to be viewed through the prism of theory of securitization as security issues, while the Copenhagen School is accepted as the analytical

\footnotetext{
1 Seven essential dimensions of human security: Economic; Food; Health; Personal; Political; Environmental; Community.
} 
framework for understanding the connection between health and security (Enemark, 2007; Elbe, 2010; Rushton and Youde, 2015; Caballero-Anthony and Cook, 2013; Pekkanen et al., 2014; Hanrieder and Kreuder-Sonnen, 2014; Kittelsen, 2013; Rushton, 2011). Securitization understood as a process in which some factor declares that a certain matter, issue or problem poses an existential threat to a designated referent object (McDonald, 2012: 119) becomes successful when it is articulated "from a specific place, in an institutional voice, by elites" (Weaver, 1995: 57). An important role in health securitization is therefore played by highranking political officials who in their statements, through a "speech act", alert to health issues as security issues which should be regulated by resolutions and strategic documents, since it was concluded at the Oslo Ministerial Conference that "threats to health may compromise a country's stability and security" (Oslo Ministerial Declaration, 2007:1).

The fact that "viruses, bacteria, and various kinds of plants and animals have never respected national borders" (Pirages \& Runci, 2000: 176-93) means that, as stated in the World Health Report, "an outbreak or epidemic in one part of the world is only a few hours away from becoming an imminent threat elsewhere" (WHO, 2007:2). Certain diseases such as HIVIAIDS and Ebola were declared an international peace and security risk by UN SC resolutions and the very concept of health security is beginning to shift toward global health security. The main advocate of global health security is now the $\mathrm{WHO}$, which has, in response to the altered health and security circumstances, revised the International Health Regulations (IHR), which have drastically reformed international legislation relevant to the international spread of disease (Fidler, 2005) as well as the relationship between the military and global health (Fidler, 2011).

By analysing literature from the field of health security, reports of relevant international organizations and national strategic documents, this paper sets out to show why health issues are considered national security issues in the $21^{\text {st }}$ century, how certain countries address these issues in their strategic documents, why the focus has been shifted from the concept of national health security to the concept of global health security, and finally, what role the WHO plays in the promotion of this concept and the securitization of health.

\section{Why is health considered to be a security issue?}

As previously mentioned, the events that marked the end of the $20^{\text {th }}$ century led not only to the emergence of new, non-traditional security risks, but also to the shifting of focus from interstate to intrastate conflicts. According to the SIPRI Yearbook data, the period from 2002 to 2011 saw 73 state-based conflicts, $40 \%$ of which in Africa, and 165 non-state conflicts, $76 \%$ of which in Africa (Neil, 2013:46; 52). Conflicts have incalculable consequences for all aspects of society, leading to deteriorating basic living conditions, a large number of civilian casualties, large-scale population displacement, but also to infectious disease outbreaks (see Figure 1). Thus the 1994 Rwandan genocide and the large number of refugees in the Democratic Republic of the Congo resulted in the spread of a cholera epidemic killing 50,000 refugees during the first month alone (WHO, 2007: 21). According to Gayer et al., malaria had been practically eradicated in Tajikistan in the early 1960s, with no more than 200-300 malaria cases reported each year before 1992. The 1992-1993 civil struggles resulted in large-scale population displacement and deteriorating living conditions. Over 
100,000 persons escaped to Afghanistan only to bring back malaria pathogens with them in 1994. An outbreak followed, reintroducing malaria in Tajikistan for the first time in 35 years. By 1997 29,794 cases were reported each year. (Gayer et al. 2007:1625).

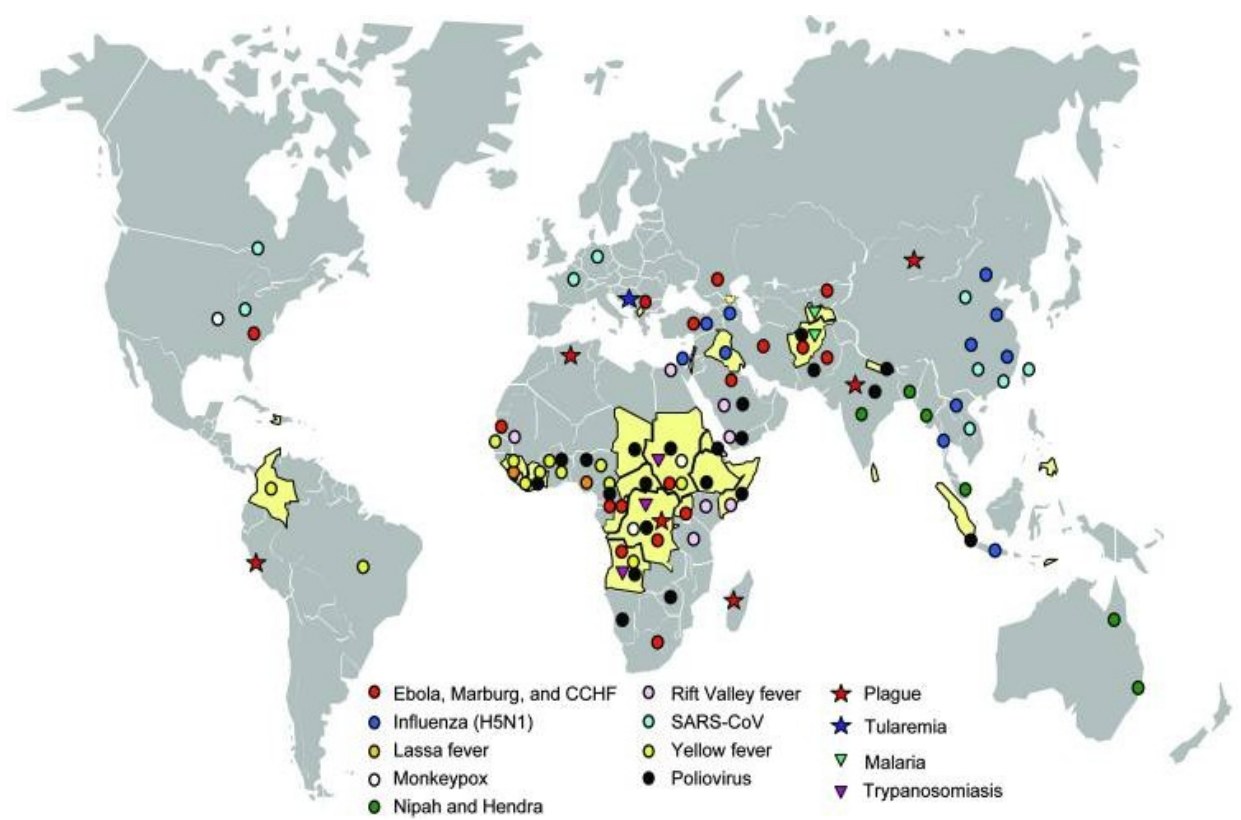

Figure 1 - Geographic distribution of emerging or re-emerging infectious disease outbreaks and countries affected by conflict, 1990-2006 (Gayer et al. 2007: 1626)

Some research also indicates that HIVIAIDS is used as a weapon of war in conflicts in Africa. During the Rwandan genocide Hutu militia members infected with the HIV virus were instructed to rape Tutsi women (Chowdhury \& Lanier, 2012:47) and, according to available data, $67 \%$ of the $200,000-535,000$ raped women in Rwanda were infected with the HIV virus (Global Justice Center, 2013). Elbe believes that HIV in conflicts in Africa can be defined "as a psychological, and perhaps even biological, weapon of war" (Elbe, 2002:168).

The fact is that today Africa is the worst affected region with 24.7 million people living with HIV, which amounts to $70 \%$ of the world's HIV-infected population. According to former US vice president AI Gore, "for the nations of sub-Saharan Africa, AIDS is not just a humanitarian crisis; it is a security crisis - because it threatens not just individual citizens, but the very institutions that define and defend the character of a society" (The White House Office of Vice President, 2000). AIDS is considered to be not only the leading cause of death in Africa, it also has a fatality rate 10 times higher than armed conflicts. Moreover, the 1995 US HIVIAIDS Strategy points out that "as the HIVIAIDS pandemic erodes economic and security bases of affected countries, it may be a potential 'war-starter' or 'war-outcome-determinant'". The Strategy pays special attention to the influence of AIDS on the armed forces and stresses that "HIV directly impacts 
military readiness and manpower, causing loss of trained soldiers and military leaders and shrinkage of recruit and conscript pools" (US Department of State, 1995). It is the belief of the US National Intelligence Council that HIV incidence in selected military populations in sub-Saharan Africa is: Angola 40-60\%, Congo-Brazzaville 10-25\%, Côte d'Ivoire 10-20\%, Democratic Republic of the Congo 40-60\%, Eritrea 10\%, Nigeria 10-20\%, and Tanzania 15-30\% (The US National Intelligence Council, 2000).

Members of the armed forces can also play a significant role in spreading the virus, particularly during peacekeeping operations. The bulk of UN peacekeeping operations take place on the territory of the African continent (9 out of 16 active peacekeeping operations). For instance, the civil war in Sierra Leone appears to have increased the number of infections partly due to the presence of peacekeepers, some of whom were from Zambia, Kenya and Nigeria, which all have high HIV incidence in the military. The realization that peacekeepers can be responsible for transmitting HIV has begun to have political implications for international peacekeeping operations, as countries refuse to host such missions for this particular reason. The impact of HIVIAIDS is also likely to render these missions increasingly unpopular among countries contributing peacekeepers to them (Elbe, 2005:4).

The consequences of conflicts, the changed living conditions and poverty have all led to migrations contributing to the spreading of existing diseases as well as newly emerging and re-emerging infectious diseases (EID). According to WHO estimates, there are currently around 1 billion migrants in the world, 214 million of whom international and 740 million internal. The rapid disease transmission is also driven by high population mobility, particularly in terms of international travel. According to World Tourism Organization data, the number of international tourists reached 1,138 million in 2014, 51 million more than in 2013 (4.7\% increase) (UNWTO, 2015:1). Besides the changed living conditions brought about by conflicts, poverty and high population mobility, Morse also cites the following causes of emerging infectious diseases: ecological changes and agricultural development; changes in human demographics and behaviour; international commerce; technology and industry; microbial adaptation and change; breakdown of public health measures and deficiencies in public health infrastructure (Morse, 1995).

In the last 25 years, more than 30 new infections have been identified, some existing ones have re-emerged, and the WHO has registered over 1,100 cases of epidemics. EID primarily affect human lives, but they can also shake public confidence in government's ability to respond, compromise the social order of a state, spark regional instability, and pose a strategic threat through bioterrorism and/or biological warfare (Brower \& Chalk, 2003: xiii). Certain authors view health securitization only through the prism of a potential bioweapons use (Kelle, 2007), which, as State Secretary Hilary Clinton has pointed out in one of her speeches, poses a threat to not only national but also global security: "we view the risk of a bioweapons attack as both a serious national security challenge and a foreign policy priority. In an age when people and diseases cross borders with growing ease, bioweapons are a transnational threat" (Rodham Clinton, 2011).

EID also have a profound impact on world economy, as observed at the 2006 World Economic Forum in Davos. The 2006 Davos Global Risk Report added pandemics to the list of risks jeopardizing the international community (World Economic Forum, 2006). Infectious diseases affect potential investment and tourism, as witnessed by the fact that gross domestic product of African countries would be $1 / 3$ higher if malaria were eradicated 
(Cecchine \& Moore, 2006:17). Furthermore, according to Gallup and Sach data, in 1995, income levels in countries with severe malaria amounted to only $33 \%$ of income levels in countries without malaria (Gallup \& Sach, 1998:1). Analysing possible economic ramifications of the use of classical biological agents, Kaufmann et al. constructed a model which shows that the economic impact of a bioterrorist attack can range from an estimated $\$ 477.7$ million per 100,000 persons exposed (brucellosis scenario) to $\$ 26.2$ billion per 100,000 persons exposed (anthrax scenario) (Kaufmann et al., 1997).

The outbreaks of infectious diseases in Asia have showed huge impact on economy and global trade (see figure 2). The 2003 outbreak of SARS showed this to be not only a health issue (in 5 months a total of 8,098 people were infected, with 774 fatalities), but also an economic problem resulting in economic losses in the amount of $\$ 50$ billion worldwide. SARS had the most dramatic economic impact in four East Asian economies with the highest incidence of probable cases: China, Hong Kong, Taiwan (China) and Singapore and Vietnam. In addition to the direct costs of intensive medical care and control interventions, SARS led to general social disruption and economic damage. Schools, hospitals and some borders were closed and thousands of people were quarantined. Many businesses collapsed, particularly in tourism-related areas, while several large production facilities were obliged to halt operations when a number of workers became infected (WHO, 2003: 78).

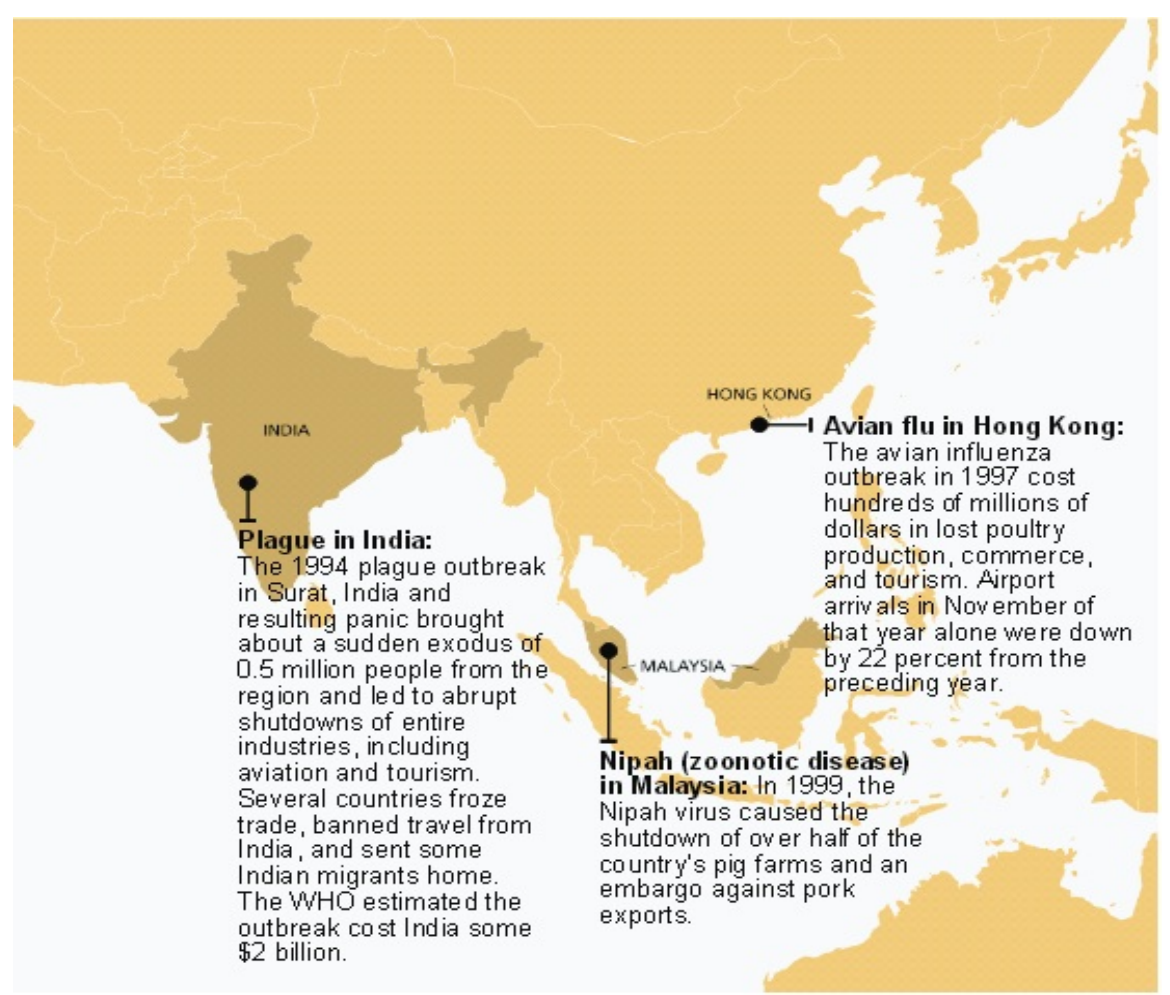

Figure 2 - Economic Impact of Infectious Disease in South East Asia (MARSH, 2008: 15) 
As Elbe has stated, SARS demonstrated that it was now 'possible legitimately to view any disease with the potential to cause significant mortality and economic damage as a national security threat" (Elbe, 2010: 46.), which was confirmed by the 2004 avian flu outbreak, the 2009 swine flu (H1N1) pandemic and the 2014 Ebola outbreak. According to Centres for Disease Control and Prevention (CDCP) data, 9936 people have died since the West African Ebola epidemic emerged in southern Guinea in December 2013 (CDCP, 2015). Based on air travel parameters and expected rates of Ebola transmission within countries at the time, World Bank analyses estimated the potential damage to the West African economy in 2015 to approximately \$1.6 billion in a "Low Ebola" scenario reflecting containment (rising to \$3.8 billion when 2014 losses were included). Estimated losses could have been as high as \$25 billion in 2015 in a "High Ebola" scenario (rising above \$32 billion when 2014 losses were included) (World Bank, 2015: 3). In March 2015, leaders of West African countries therefore urged the world "to back a 'Marshall Plan' to help them stamp out the disease and rebuild their shattered economies" (Aljazeera America, 2015). The above data justify SC UN Resolution 2177, adopted in 2014, which confirmed "that the unprecedented extent of the Ebola outbreak in Africa constitutes a threat to international peace and security" (UN Security Council Resolution 2177, 2014).

Bearing in mind all the aforementioned consequences of infectious diseases, certain health issues have started to be considered threats to not only national but also global security, while the concept of health security is moving toward global health security, which first appeared in the WHO report "Global health security: epidemic alert and response" (WHO, 2001) and was elaborated in detail in the report "A Safer Future: Global Health Security in the $21^{\text {st }}$ Century" (WHO, 2007). According to the aforementioned report, global health security was defined as "activities required, both proactive and reactive, to minimize vulnerability to acute public health events that endanger the collective health of populations living across geographical regions and international boundaries" and threats to global health security as threats which have an impact on "economic or political stability, trade, tourism, access to goods and services and, if they occur repeatedly, on demographic stability" (WHO, 2007:1).

Since health issues pose a threat to stability and security and health being inextricably linked with the environment, trade, economic growth, social development, national security, and human rights and dignity, initiatives have been launched to incorporate health issues into the foreign policy agenda, as highlighted in Oslo Ministerial Declaration. After this Declaration, the 2008 UN General Assembly adopted the first resolution on global health and foreign policy, Resolution 63/33. This Resolution was followed by a series of others (resolutions 64/108, 65/95, 66/115, 67/81, 68/98), with the UN General Secretary's Report "Global health and foreign policy: strategic opportunities and challenges" emphasizing that "global health touches upon all the core functions of foreign policy: achieving security, creating economic wealth, supporting development in low-income countries and protecting human dignity" (UN, 2009: 2). Consequently, global health security has become part of foreign policy agendas in many countries and has been included in the discussion on both national security and commerce and diplomacy (Katz et. al, 2011). The US has become a leader in promoting the connection between health and national and/or international security, while the WHO has become the most significant forum for interstate discussions on international health issues, that is, one of the main actors in global health or disease diplomacy (Davies et al., 2015:7), as will be shown in the following sections. 


\section{Health security policies and national security strategies}

A year after passing the 1995 HIV Strategy, the then US President Bill Clinton issued the Presidential Decision Directive NSTC-7, which confirmed that infectious diseases such as Ebola, tuberculosis and HIVIAIDS "present one of the most significant health and security challenges facing the global community" (The White House, 1996). The US National Intelligence Council also gave health issues special consideration by publishing in 2000 a special report on the threat of global infections to the US and identifying AIDS and other infectious diseases as a national security issue (National Intelligence Council, 2000).

In the ensuing period, the US became a leader in promoting the connection between health and national and/or international security and US efforts to present HIVIAIDS as a security issue resulted in the UN SC organizing in 2000 the first ever meeting on 'The impact of AIDS on peace and security in Africa - security implications of the disease in Africa', dedicated entirely to non-traditional security threats (UN Security Council 4087 Meeting, 2000). This meeting resulted in the adoption of Resolution 1308, which classified HIV as a threat to stability and security and declared a "peaceful war against AIDS" (Economic and Social Council Press Release ECOSOC/5884, 2000). Having in mind the high HIVIAIDS prevalence among members of the armed forces, as well as the fact that today most conflicts and peacekeeping operations take place on the African continent, at UN Security Council 6547 Meeting in 2011, a new resolution was adopted, namely Resolution 1983, which emphasized the role of UN peacekeeping missions in the global response to AIDS (UN Security Council Resolution 1983, 2011). The United Nations and the Security Council took on the role of the securitizing actor, while infectious diseases and health issues became security issues in the context of theory of securitization.

Fidler cites that besides AIDS, significant health issues from the standpoint of national and international security include infectious diseases, concerns over the proliferation of bioweapons and fears of terrorist use of bioweapons - bioterrorism (Fidler, 2003: 791-2).

The fear of bioweapons use became justified in 2001, when anthrax spores were mailed to US Congress. Centres for Disease Control and Prevention identified 22 cases of anthrax poisoning, five of which were fatal (Das \& Kataria, 2010: 225). According to Ingram, this attack brought public health "onto the frontline of homeland security" (Ingram, 2008: 77) and led to the founding of the Global Health Security Initiative $(\mathrm{GHSI})^{2}$, aimed at strengthening mechanisms of combating and responding to chemical, biological, radiological and nuclear terrorism. Shortly after it was founded, the GHSI expanded its mandate to include threats of an influenza pandemic since, as the then US President George W. Bush pointed out in his speech to US National Institutes for Health in 2005, a potential influenza pandemic is not only a "vital issue to the health and safety of all Americans", but also a "danger to our homeland", explaining that the global implications of an influenza pandemic meant that "no nation can afford to ignore this threat" (President George W. Bush, 2005). All this resulted in the adoption of the National Strategy for Pandemic Influenza, which stressed that pandemics could have "significant implications for the economy, national security, and the basic functioning of society" (Homeland Security Council, 2006: ix).

\footnotetext{
${ }^{2}$ This Initiative was launched in November 2001 by Canada, the European Union, France, Germany, Italy, Japan, Mexico, the United Kingdom and the United States.
} 
By 2010, the US alone had signed 31 bilateral agreements on health issues, 20 of which targeted the prevention and mitigation of specific infectious diseases (Katz et al., 2011:506), while the connection between infectious diseases and security is a key element in a series of other strategic documents in the US, including the National Health Security Strategy and Implementation Plan (NHSS/IP) 2015-2018 (issued in February 2015) and the 2015 National Security Strategy, which classifies severe global infectious disease outbreaks as top strategic risks to the national interest and emphasizes that America is the "world leader in fighting pandemics, including HIVIAIDS, and improving global health security" (The White House, 2015:14).

A specific role in health securitization is also played by the $\mathrm{EU}$, which defines global health as "those health issues which transcend national boundaries and governments and calls for actions to influence the global forces that determine the health of people" (Kickbusch \& Lister, 2006: 7). EU participates in this process through the GHSI and the Health Security Committee (HSC), founded in 2001 during a discussion in the wake of the bioterrorist attacks in the US. In 2007 the HSC expanded its mandate to include influenza preparedness and response; public health preparedness and response to chemical, biological and radio nuclear (CBRN) attacks; and generic preparedness and response for public health emergencies (European Commission, 2009).

Another important actor in this process is the European Centre for Disease Prevention and Control (ECDC), founded in 2005 in the wake of a SARS epidemic. The $E C D C$ is an EU agency whose main goal is strengthening Europe's defences against infectious diseases, with a mission to identify, evaluate and convey existing and emerging threats to human health from infectious diseases. The avian flu pandemic also prompted the adoption of the European Parliament's first resolution on pandemic influenza preparedness and response planning in the European Community (European Parliament, 2006) and the conclusion of the Council of the European Union on human security, which underlined that "the intensification and globalization of trade, the increase in European and international travel and climate change constitute factors that may contribute to the spread of pathogens in the European Union (EU) or to pathogens not previously present becoming established in Europe" and cited measures of cooperation between member countries in the field of health security in keeping with International Health Regulations 2005 (Council of the European Union, 2008).

The connection between health and security and the viewing of health issues as security issues have found their place in national security strategies of other countries. Thus, the UK's National Security Strategy emphasized that "the risk of human pandemic disease remains one of the highest we face" (HM Government, 2010: 30), while the 2013 National Risk Register classified the risk of pandemic influenza as the highest priority risk (Cabinet Office, 2013). The 2013 French White Paper on Defence and National Security also classified risks of pandemics among major risks: "we face the risk, in particular, of a new highly pathogenic and lethal pandemic caused, for instance, by the emergence of a new virus that crosses the species barrier, or by the escape of a virus from a biocontainment laboratory" (President of French Republic, 2013: 44). Russia's National Security Strategy to 2020 cites a broad spectrum of epidemics and pandemics as the most significant threat in terms of health and national security, with a focus on the mass spread of the HIV infection (President of the Russian Federation, 2009). According to 
available data, there were 390,365 registered cases in 2007 in Russia, while today there are an estimated 1.2 million cases, most of whom are young people, which bears significantly on recruitment to the armed forces. Between 2000 and 2005, several thousand potential recruits could not serve in the armed forces in Russia because they were HIV positive (Twigg, 2007: 7).

The consequences of the 2003 SARS outbreak in Asia prompted Asian countries to pay more attention to non-traditional security threats. In 2003, in just five months, SARS killed more than 700 people and, according to the Asia Development Bank, caused an estimated damage of about $\$ 18$ billion in East Asia, or around $0.6 \%$ of the gross domestic product (Bloom et al., 2005: p. 1). The Philippines' national security adviser stated that "SARS threat was greater than any threat of terrorism in the country" (cited in Caballero-Anthony, 2006: 112). Bearing in mind the consequences of SARS, Asian countries entered talks on health security which resulted in a special ASEAN-China Leaders Meeting held on 29 April 2003 in Bangkok, where joint measures against health threats were adopted, namely measures concerning exchange of information and good practices in the combat against infectious diseases, promotion of cooperation in health care, immigration and customs control, coordination of travel procedures, etc. (Joint Statement of the Special ASEAN-China Leaders Meeting on the Severe Acute Respiratory Syndrome (SARS), 2003).

While nowadays health issues are included in discussions on national security and foreign policy of many countries, the most significant forum for interstate discussion on international health issues is the WHO. The following section will present the WHO's activities in the domain of global health security.

\section{WHO and Global Health Security}

The emergence of new diseases and their mass spread in the $21^{\text {st }}$ century made the WHO, founded in 1948 with the aim of guiding and coordinating the health system within the United Nations, the most relevant forum for interstate discussions on international health issues and an advocate of the concept of global health security. Although the agreements negotiated in the WHO are few, they are considered important; these are, first and foremost, the WHO Framework Convention on Tobacco Control and the revised International Health Regulations, which is far more relevant to this paper (Katz et al, 2011: 506). Namely, pursuant to Articles 21(a) and 22, the Constitution of WHO grants the World Health Assembly authority to pass regulations "designed to prevent the international spread of disease" (Basic Documents, 2006). The International Health Regulations were adopted by the Health Assembly in 1969 to protect against the international spread of three diseases namely, yellow fever, cholera, and plague "quarantinable diseases". Although the IHR have been revised several times since their adoption, Fidler cites three major problems in their implementation: the restricted number of infectious diseases subject to the IHR, the States Parties' failure to inform the WHO of outbreaks of diseases and to comply with the maximum measures applicable to the trade and travel originating from countries affected by outbreaks of diseases subject to the IHR (Fidler, 2005). 
By the 1990s, the global health community had realized that the threat of emerging (e.g. Ebola virus) and re-emerging (e.g. dengue) infectious diseases was rising. The tools for coordinating the international response to trans-border outbreaks had obviously become lacking. This realization led to the adoption of a resolution at the 1995 World Health Assembly aimed at revising the International Health Regulations and the launching of an initiative in 1996 for a new global infectious disease surveillance and response platform - Global Outbreak Alert and Response Network (GOARN). GOARN was created in April 2000 with primary aims to: assist countries with disease control and combating the international spread of outbreaks; investigate and characterize events and assess risks of rapidly emerging epidemic disease threats; support national outbreak preparedness and capacity building. According to available data, since 2000 , WHO and GOARN have responded to more than 50 events worldwide with over 400 experts providing field support to 40 countries.

In 2005 the Health Assembly adopted the Revised International Health Regulations, whose main purpose and goal, pursuant to Article 2, is "to prevent, protect against, control and provide a public health response to the international spread of disease in ways that are commensurate with and restricted to public health risks, and which avoid unnecessary interference with international traffic and trade." (WHO, 2008:10). In fact, the IHR are an instrument to address today's challenges, especially public health emergency of international concern. Public health emergency of international concern as defined by the IHR is "an extraordinary event which is determined to constitute a public health risk to other States through the international spread of disease and to potentially require a coordinated international response" (WHO, 2008:9). This definition involves a situation that is grave, uncommon or unforeseen, has implications for public health outside the national borders of the affected state, and might necessitate prompt international action. The report "A Safer Future: Global Health Security in the $21^{\text {st }}$ Century" explores a range of threats to health security under the framework of the IHR: human causes of health insecurity; inadequate investment; unexpected policy changes; public health consequences of conflict; microbial evolution and antibiotic resistance; animal husbandry and food processing; weather-related events and infectious diseases; other public health emergencies; chemical events; radioactive events (WHO, 2007:17-35).

The IHR stipulate the legal framework for joint responsibility in global health security and define the roles, duties and core capacities for member states and the WHO. In fact, according to Fidler, the new IHR include five major changes from the previous regime: (1) broadening the scope of the IHR significantly; (2) obliging States Parties to create minimum core surveillance and response capacities; (3) conferring the WHO authority to access and use non-governmental sources of surveillance information; (4) giving the WHO power to declare public health emergencies of international concern and give recommendations on how such emergencies and routine public health risks should be handled by States Parties; and (5) incorporating human rights concepts into States Parties' application of the IHR (Fidler, 2005).

Under the revised IHR, changes were made to core missions and tasks of the armed forces. Namely, military health services have unique capabilities that can contribute to global public health under the International Health Regulation (2005) framework, 
particularly in surveillance such as that of the French Military Influenza Surveillance System (MISS) and the US Armed Forces Health Surveillance Centre Global Emerging Infectious Surveillance and Response System (AFHSC-GEIS) (Ho et al., 2014) and laboratory support (Chretien et al., 2007). Fidler argues that the military may make its contribution by strengthening the military's own capacities in disease surveillance and response; supporting civilian efforts at home and abroad to build detection and intervention capacities; supplementing civilian capacity in contexts where such capacity is inadequate or ineffective because of insecure conditions; helping foreign militaries build their IHR (2005)-relevant capacities; and assisting development agencies build capabilities in developing and least-developed countries (Fidler, 2011). In the most recent article on securitization and military role, Watterson and Kamradt-Scott argue that militaries can be powerful agents for pandemic preparedness and response, whose role is justified on the grounds of their capability to expand civilian programs, contribute to the national pandemic response, and lessen the impact of influenza on their own forces and military objectives (Watterson \& Kamradt-Scott, 2015).

\section{Conclusion}

This paper explains why certain health issues are considered security risks and identifies the major actors in the health securitization process and global health diplomacy. The expansion of international travel and trade, the emergence or reemergence of international disease threats and other public health risks, and the impetus from the appearance of severe acute respiratory syndrome (the first global public health emergency of the $21^{\text {st }}$ century), have made the concept of health security an issue of growing relevance in both academic and political discourse. Our analysis of relevant literature and various reports has shown that this concept is linked to not only the mass spread of infectious diseases but also the possibility of using pathogen microorganisms as bioweapons and to the fact that certain diseases can have social, political, economic and military implications thereby jeopardizing stability and security. Therefore, pandemics of infectious diseases, along with the fear and concerns over a potential use of biological agents for terrorist purposes, have led to certain health issues being viewed through the theory of securitization as security risks and, as such, have found their place in national security strategies and foreign policy agendas of certain countries. The US has become a leader in promoting the connection between health and security and its efforts to present HIVIAIDS as a security issue resulted in the UN SC organizing in 2000 the first ever meeting on non-traditional security threats and adopting a historic resolution which defined HIV as a threat to stability and security. After the adoption of this resolution and in the wake of pandemics such as SARS, H5N1, H1N1, and Ebola in 2014, which the UN SC marked as a threat to international peace and security, more attention has been given to the concept of global health security, whose main supporter is the WHO. In 2005, when the revised IHR granted the WHO power to declare the existence of public health emergencies of international concern, the WHO became the most relevant forum for interstate discussions on global health issues and the main actor in global health diplomacy. 


\section{References}

[1] Alkire, S. (2003). A Conceptual Framework for Human Security. University of Oxford: Centre for Research on Inequality, Human Security and Ethnicity.

[2] Aljazeera America (2015). West African leaders urge Ebola 'Marshall Plan' Available at: http://america.aljazeera.com/articles/2015/3/3/african-leaders-urge-ebola-marshall-plan.html (accessed 22 March 2015).

[3] Baker, M. G., \& Fidler, D. P. (2006). "Global Public Health Surveillance under New International Health Regulations". Emerging Infectious Diseases, 12(7), 1058-1065.

[4] Basic Documents (2006) Constitution of the World Health Organization. Available at: http://www.who.int/governance/eb/who_constitution_en.pdf (accessed 11 March 2015).

[5] Brower, J. and Chalk, P. (2003). Global Threat of New and Reemerging Infectious Diseases: Reconciling US National Security and Public Health Policy. Santa Monica: RAND.

[6] Bloom, E., et al. (2005). Potential Economic Impact on an Avian Flu Pandemic on Asia. Asian Development Bank.

[7] Caballero-Anthony, M. and Cook, A. (2013). Non-Traditional Security in Asia: Issues, Challenges and Framework for Action. Singapore: Institute of Southeast Asian Studies.

[8] Caballero-Anthony, M. (2006). "Combating Infectious Diseases in East Asia: Securitization and Global Public Goods for Health and Human Security". Journal of International Affairs 59(2).

[9] Chowdhury, I., Lanier, M. (2012). "Rape and HIV as Methods of Waging War: Epidemiological Criminology's Response". Advances in Applied Sociology. 2(1): 47-52.

[10] Cecchine, G., Moore, M. (2006). Infectious Disease and National Security Strategic Information Needs. Santa Monica: RAND.

[11] Curley, M., Herington, J. (2011). "The securitisation of avian influenza: international discourses and domestic politics in Asia". Review of International Studies.37 (1): 141166.

[12] Cabinet Office (2013). National Risk Register of Civil Emergencies 2013 Edition Available at: https://www.gov.uk/government/uploads/system/uploads/attachment_data/file/211867/NationalRisk Register2013_amended.pdf (accessed 12 March 2015).

[13] Council of the European Union (2008) Council Conclusion on health security Available at: http://www.consilium.europa.eu/ueDocs/cms_Data/docs/pressdata/en/lsa/104770.pdf (accessed 02 March 2015).

[14] Chretien, J. et al. (2007). The importance of militaries from developing countries in global infectious disease surveillance. Bulletin of the World Health Organization, 85(3): 174-180.

[15] Centres for Disease Control and Prevention (CDCP) 2014 Ebola Outbreak in West Africa - Case Counts. Available at: http://www.cdc.gov/vhf/ebola/outbreaks/2014-west-africa/casecounts.html (accessed 22 March 2015).

[16] Dixon, S., McDonald, S. and Robert, J. (2002). "The impact of HIV and AIDS on Africa's economic development". BMJ 324(7331): 232-234.

[17] Das, S., Kataria, VK. (2010). "Bioterrorism: A Public Health Perspective". MJAFI, 66(3): 255

[18] Davies, S., Kamradt-Scott, A.and Rushton, S. (2015). Disease Diplomacy: International Norms and Global Health Security. Baltimore: John Hopkins University Press.

[19] European Commission (2009). Background on the Health Security Committee and the Early Warning and Response System authorities. Available at: http://europa.eu/rapid/pressrelease_MEMO-09-363_en.htm (accessed 12 March 2015). 
[20] European Parliament (2006). Resolution on pandemic influenza preparedness and response planning in the European Community (2006/2062(INI)) Available at: http://www.europarl.europa.eu/sides/getDoc.do?type=TA\&reference=P6-TA-20060259\&language=BG\&ring=A6-2006-0176 (accessed 22 March 2015).

[21] Economic and Social Council Press Release ECOSOC/5884 (2000) International Security Includes 'Peaceful War Against AIDS, Economic and Social Council told Available at: (http://www.un.org/press/en/2000/20000228.ecosoc5884.doc.html (accessed 10 March 2015).

[22] Ejdus, F. (2012). Međunarodna bezbednost: teorije, sektori i nivoi. Beograd: JP Službeni glasnik i Beogradski centar za bezbednosnu politiku.

[23] Enmark, C. (2007). Disease and Security: Natural Plagues and Biological Weapons in East Asia. New York: Routledge.

[24] Elbe, S. (2005). "AIDS, security, biopolitics. International Relations 19(4): 403-419.

[25] Elbe, S. (2005). "The Security Implications of HIVIAIDS". Politique Etrangere 1.

[26] Elbe, S. (2006). "Should HIVIAIDS be securitized? The ethical dilemmas of linking HIVIAIDS and security". International Studies Quarterly 50(1): 119-144.

[27] Elbe, S. (2009). Virus Alert: Security, Governmentality and the AIDS Pandemic. New York: Columbia University Press.

[28] Elbe, S. (2010). Security and Global Health. Cambridge: Polity Press.

[29] Elbe, Stefan (2002). "HIVIAIDS and the Changing Landscape of War in Africa". International Security, 27 (2): 168.

[30] Fidler, D. (2003). "Public Health and National Security in the Global Age: Infectious Diseases, Bioterrorism, and Realpolitik. Faculty Publications. Paper 416.

[31] Fidler, D. (2005). "From International Sanitary Conventions to Global Health Security: The New International Health Regulations". Chinese Journal of International Law. 4 (2): 325-392.

[32] Fidler, D. (2011). "Navigating the Global Health Terrain: Mapping Global Health Diplomacy" Faculty Publications. Paper 820. http://www.repository.law.indiana.edu/facpub/820.

[33] Gallup, John Luke \& Sachs, Jeffery (1998). The Economic Burden of Malaria. Center for International Development at Harvard Available at http://earth.columbia.edu/sitefiles/file/about/director/pubs/mal_wb.pdf

[34] Gayer, M. et al. (2007). "Conflict and Emerging Infectious Diseases". Emerging Infectious Diseases 13(11): 1625 - 1631.

[35] Global Justice Center (2013). Q\&A: How the Systemic Discrimination against Women in Weapons Classification and Enforcement is a Serious Violation of International Humanitarian Law. Available at: http://www.peacewomen.org/assets/file/Resources/lawref_discrimination_jan_2012.pdf (accessed 22 March 2015).

[36] Hanrieder, T., Kreuder-Sonnen, C. (2014). "WHO decides on the exception? Securitization and emergency governance in global health." Security Dialogue. 45(4): 331-348.

[37] Homeland Security Council (2006). National Strategy for Pandemic Influenza Implementation Plan. Available at: http://www.flu.gov/planning-preparedness/federal/pandemicinfluenza-implementation.pdf (accessed 22 March 2015).

[38] HM Government (2010). A Strong Britain in an Age of Uncertainty: The National Security Strategy. Available at:

https://www.gov.uk/government/uploads/system/uploads/attachment_data/file/61936/nationalsecurity-strategy.pdf (accessed 12 February 2015).

[39] Ho, Z. J. M., Hwang, Y. F. J., \& Lee, J. M. V. (2014). "Emerging and re-emerging infectious diseases: challenges and opportunities for militaries". Military Medical Research, 1, 21. 
[40] Ingram, A. (2008). "Pandemic Anxiety and Global Health Security" In: Pain, R. and Smith, S.(eds). Fear: Critical Geopolitics and Everyday Life. Hampshire: Ashgate Publishing, Ltd.

[41] Joint Statement of the Special ASEAN-China Leaders Meeting on the Severe Acute Respiratory Syndrome (SARS), 2003. Available at: http://www.asean.org/communities/aseansocio-cultural-community/item/joint-statement-of-the-special-asean-china-leaders-meeting-on-thesevere-acute-respiratory-syndrome-sars (accessed 22 February 2015).

[42] Katzz, R. et al. (2011). "Defining Health Diplomcy: Changing Demands in the Era of Globalization". The Milbank Quarterly 89(3): 503 - 523.

[43] Kaufmann, A., Melzer, M. and Schmid, G. (1997). "The Economic Impact of a Bioterrorist Attack: Are Prevention and Postattack Intervention Programs Justifiable?" Emerging Infectious Diseases 3 (2):83-94.

[44] Kelle, A. (2007). "Securitization of International Public Health: Implications for Global Health Governance and the Biological Weapons Prohibition Regime" Global Governance, 13 (2): 217-235.

[45] Kittelsen, K. (2013). The EU and the Securitization of Pandemic Influenza. Thesis submitted in fulfillment of the requirements for the degree of Ph.D. Department of International Politics Aberystwyth University.

[46] Kickbusch, I.a and Lister, G. (eds.) (2006). European Perspectives on Global Health: A Policy Glossary. Brussels: European Foundation Centre. Available at:

http://www.efc.be/programmes_services/resources/Documents/EFC_EPGH_GlobalHealthGlossary-1.pdf (accessed 02 February 2015).

[47] Makdonald, M. (2012). "Konstruktivizam". U: Vilijams, P. (ur) Uvod u studije bezbednosti. Beograd: JP Službeni glasnik i Fakultet bezbednosti.

[48] MARSH (2008). The Economic and Social Impact of Emerging Infectious Disease: Mitigation through Detection, Research, and Response Available at :

http://www.healthcare.philips.com/main/shared/assets/documents/bioshield/ecoandsocialimpactofe merginginfectiousdisease_111208.pdf (accessed 26 February 2015).

[49] Morse, SS (1995) "Factors in the Emergence of Infectious Diseases". Emerg Infect Dis [serial on the Internet]. Available from http://wwwnc.cdc.gov/eid/article/1/1/95-0102 (accessed 26 March 2015).

[50] McInnes, C. and, Ruthon, S. (2012). "HIV/AIDS and securitization theory". European Journal of International Relations 19(1): 115 - 138.

[51] National Intelligence Council (2000). National Intelligence Estimate: The Global Infectious Disease Threat and Its Implications for the United States. Available at:

http://www.wilsoncenter.org/sites/default/files/Report6-3.pdf (accessed 05 February 2015).

[52] Newman, E. (2004). "The 'New Wars' Debate: A Historical Perspective Is Needed". Security Dialogue 35 (2): 173-189.

[53] Neil, M. (2013). "Armed conflict". In SIPRI Yearbook 2013. Oxford: Oxford University Press

[54] Oslo Ministerial Declaration—global health: a pressing foreign policy issue of our time (2007). Available at: http://www.who.int/trade/events/Oslo_Ministerial_Declaration.pdf (accessed 26 February 2015).

[55] Paris, R. (2001). "Human Security Paradigm Shift or Hot Air?" International Security, 26(2): 87-102.

[56] Pekkanen, S. et. al (2014). The Oxford Handbook of the International Relations of Asia. New York: Oxford University Press.

[57] Pirages D, Runci P. (2000). "Ecological interdependence and the spread of infectious disease". In: Cusimano M (ed.). Beyond Sovereignty: Issues for a Global Agenda. New York: St Martins Press, pp. 176-93.

[58] President George W. Bush (2005). President Outlines Pandemic Influenza Preparations and Response. Remarks at William Natcher Center, National Naval Medical Center Bethesda, Maryland. Available at: http://2001-2009.state.gov/g/oes/rls/rm/55882.htm (accessed 22 March 2015). 
[59] President of French Republic (2013). French White Paper Defence and National Security. Available at: www.defense.gouv.fr/.../White\%20paper\%20on (accessed 22 March 2015).

[60] President of the Russian Federation (2009). Russia's National Security Strategy to 2020. Available at: http://www.isn.ethz.ch/Digital-Library/Publications/Detail/?id=154915 (accessed 22 March 2015).

[61] Rodham Clinton, Hillary (2013). Remarks at the 7th Biological and Toxin Weapons Convention Review Conference. Available at:

http://www.state.gov/secretary/20092013clinton/rm/2011/12/178409.htm (accessed 22 March 2015)

[62] Rusthon, S., Youde, J. (eds.) (2014). Routledge Handbook of Global Health Security. New York: Routledge.

[63] Rushton, S. (2011). "Global Health Security: Security for Whom? Security from What?" Political Studies 59(4):779-796.

[64] Security Council $4087^{\text {th }}$ Meeting (2000). The impact of AIDS on peace and security in Africa. Available at: (http://www.securitycouncilreport.org/atf/cf/\%7B65BFCF9B-6D27-4E9C-8CD3CF6E4FF96FF9\%7D/CC\%20SPV\%204087.pdf) (accessed 25 March 2015.)

[65] The White House (1996). Presidential Decision Directive (NSTC-7). Available at: https://fas.org/irp/offdocs/pdd/pdd-nstc-7.pdf (accessed 20 March 2015).

[66] The White House Office of Vice President (2000). Remarks as prepared for delivery by Vice President Al Gore U.N. Security Council session on AIDS in Africa. Available at: http://www.state.gov/1997-2001-NOPDFS/global/oes/health/000110_gore_hiv-aids.html (accessed 20 March 2015).

[67] The U.S. National Intelligence Council (2000). The Global Infectious Disease Threat and Its Implications for the United States. Available at: http://fas.org/irp/threat/nie99-17d.htm (accessed 20 March 2015).

[68] The White House (2015). National Security Strategy. Available at: http://www.whitehouse.gov/sites/default/files/docs/2015_national_security_strategy.pdf (accessed 22 March 2015).

[69] Twigg, J. (2007). "HIVIAIDS in Russia: Commitment, Resources, Momentum, Challenges". A Report of the Task Force on HIVIAIDS Center for Strategic and International Studies. Washington: The Center for Strategic and International Studies. Available at:

http://csis.org/files/media/csis/pubs/071016_russiahivaids.pdf (accessed 11 March 2015).

[70] UNDP Human Development Report (1994). Available at:

http://hdr.undp.org/sites/default/files/reports/255/hdr_1994_en_complete_nostats.pdf (accessed 22 February 2015).

[71] UNWTO (2015) World Tourism Barometer Vol. 13 Available at: http://dtxtq4w60xqpw.cloudfront.net/sites/all/files/pdf/unwto_barom15_01_january_excerpt_1.pdf (accessed 22 March 2015).

[72] U.S. Department of State (1995). US International Strategy on HIV/AIDS Bureau of Oceans, International Scientific and Environmental Affairs. Available at: http://dosfan.lib.uic.edu/ERC/environment/releases/9507.html (accessed 02 February 2015).

[73] U.S. Department of Defence (2014) DoD Ebola Related Activities Costs. Available at: http://www.defense.gov/home/features/2014/1014_ebola/ (accessed 19 March 2015).

[74] UN Secretary-General's report (2009). Global Health and Foreign Policy: Strategic Opportunities and Challenges. Available at: http://www.who.int/trade/foreignpolicy/FPGH.pdf (accessed 19 March 2015).

[75] UN Security Council 4087 Meeting (2000). The impact of AIDS on peace and security in Africa. Available at: (http://www.securitycouncilreport.org/atf/cf/\%7B65BFCF9B-6D27-4E9C-8CD3CF6E4FF96FF9\%7D/CC\%20SPV\%204087.pdf) (accessed 15 March 2015). 
[76] UN Security Council Resolution 1983 (2011). Available at:

http://www.unaids.org/sites/default/files/sub_landing/files/20110607_UNSC-Resolution1983.pdf (accessed 15 March 2015).

[77] UN Security Council Resolution 2177 (2014). Available at: http://www.ifrc.org/docs/IDRL/UN\%20SC\%20Res.pdf (accessed 15 March 2015).

[78] Watterson, Christopher and Kamradt-Scott, Adam (2015) "Fighting Flu: Securitization and the Military Role in Combating Influenza". Armed Forces \& Society 1-24.

[79] World Health Organization (2008). International Health Regulations (2005) Second Edition. Geneva: WHO Press.

[80] World Health Organization (2001) Global health security: epidemic alert and response http://apps.who.int/medicinedocs/documents/s16357e/s16357e.pdf (accessed 16 March 2015).

[81] Waever, O. (1995). 'Securitisation and Desuritisation', in Ronny L. (ed.), On Security: 46-87. New York: Columbia University Press.

[82] World Economic Forum (2006). Global Risk 2006. Available at: http://www.weforum.org/pdf/CSI/Global_Risk_Report.pdf (accessed 19 March 2015).

[83] World Bank (2013). World Bank and HIV/AIDS: The Facts. Available at: http://www.worldbank.org/en/topic/hivandaids/brief/world-bank-and-hivaids-the-facts (accessed 11 March 2015).

[84] World Bank (2015). The Economic Impact of Ebola on Sub-Saharan Africa: Updated Estimates for 2015. Available at:

https://openknowledge.worldbank.org/bitstream/handle/10986/21303/937210REVISED000Jan020 02015000FINAL.pdf?sequence=1 (accessed 22 March 2015).

[85] World Health Organization (2003). The World Health Report: Shaping the Future. Available at: http://www.who.int/whr/2003/en/whr03_en.pdf (accessed 22 March 2015). 